\title{
THE RUSSIAN REVIEW
} An American Quarterly Devoted to Russia Past and Present

Table of Contents, Vol. XVI, No. 2, April 1957

Articles

Paul Miliukov-Historian and Statesman ........... Alexis Goldenweiser The Role of the Military in Recent Soviet Politics . . . . . . Raymond L. Garthoff Sholokhov and Tolstoy $\ldots \ldots \ldots \ldots \ldots \ldots \ldots \ldots$ Helen Muchnic

The Russian Revolution and Wilson's Far-Eastern Policy . . Betty M. Unterberger Clues to the Soviet Political Archives ............. John A. Armstrong The Imperial Russian General Staff and India .......... Warren B. Walsh

Book Reviews

Book Notices

Subscription, $\$ 5.00$ a year, single copies $\$ 1.25$

THE RUSSIAN REVIEW

235 Baker Library

Hanover, N. H.

\section{THE REVIEW OF POLITICS}

\author{
A Quarterly Published by \\ The University of Notre Dame
}

The April 1957 issue will include the following articles:

Josef Pieper, Knowledge and Freedom.

Henry S. Albinski, The Concept of Partnership in the Central African Federation.

Hans Kohn, Nationalism in the Low Countries.

Leo R. Ward, John Dewey in Search of Himself.

W. F. Murphy, The Political Thought of Gerrord Winstanley.

Annual Subscriptions: U.S. and Pan-American, $\$ 5.00$;

Foreign, $\$ 5.40$. Single issues, $\$ 1.50$ each.

Address: The Editors, Review of Politics,

P.O. Box 4, Notre Dame, Indiana. 


\section{INDIAN PRESS DIGESTS}

\section{ELECTIONSIN INDIA \\ (1951 through 1956)}

- Election procedures, political porties, voter response

- Statistical analyses of elections and by-elections

- The low, the courts, the couses of by-elections

- Elections in Travancore-Cochin and PEPSU (1954); Andhro (1955)

- Twenty-one tables; two constituency maps of Anchra

INDIAN PRESS DICESTS-Monograph No. 3

The Indian Experience with Democratic Elections

200 poges

$\$ 1.50$

Order from

INDIAN PRESS DIGESTS

UNIVERSITY OF CALIFORNIA-BERKELEY 4, CALIF.

\section{in the Winter issue of}

\section{THE MIDDLE EAST JOURNAL}

IRAN: A TVA FOR THE KHUZESTAN REGION

Gordon R. Clapp, former head of the Tennessee Valley Authority, discusses plans for Iranian development

THE PROBLEM OF REGIONAL SECURITY IN THE MIDDLE EAST: AN APPRAISAL

MAJID KHADDLRI examines the reasons for previous failures and the likelihood of future success of security systems

THE IMPACT OF URBANIZATION IN ISRAEL

Bernard D. Weinry describes demographic change in Israel

THE JAMA'AT-I-ISLAMI OF PAKISTAN

FrakLAND ABBotT analyzes the workings of a religious party

THE KURDS OF IRAQ

C. J. EDMonvs reports on the current status of Iraq's largest minority

$\$ 1.50$ per copy

$\$ 6.00$ per year

THE MIDDLE EAST INSTITUTE

1761 N ST., N.W. WASHINGTON 6, D.C. 